\title{
Assay of anti-D using the Technicon AutoAnalyzer and the international standard anti-D typing serum
}

\author{
W. J. JUDD AND W. J. JENKINS \\ From the North-East Metropolitan Regional Blood Transfusion Centre, Crescent Drive, Brentwood, \\ Essex, England
}

SYNOPSIS A method is described for the automated quantitation of the anti-D content of sera. This procedure is far more reproducible than current manual techniques. The use of the International Standard anti-D typing serum in the calibration of a working standard enables results to be expressed in $\mu \mathrm{g} / \mathrm{ml}$ of antibody protein.

When red cell antibodies are titrated by conventional doubling dilution techniques, the end points recorded by different individuals using the same sera can vary considerably. Even a difference of one tube will affect the results by plus or minus $100 \%$.

Marsh, Nichols, and Jenkins (1968) described certain modifications to the Technicon antibody screening machine which increased its sensitivity for the detection of red cell antibodies. The same authors emphasized the restriction on the supply of fresh suitably genotyped red cells, a factor which severely limits the widespread use of the AutoAnalyzer for antibody screening. However, the method they described, with one or two further modifications, is highly successful for the quantitation of rhesus antibodies. Parallel investigations of the same sera by different workers are in close agreement and almost always within the range of $\pm 20 \%$.

By making use of the International Standard anti-D typing serum (Goldsmith, Mourant, and Bangham, 1967) for the calibration of a working standard, the anti-D content of test sera can be expressed in terms of micrograms of antibody protein per millilitre.

\section{Method}

The AutoAnalyzer is set up according to the flow diagram described by Marsh et al (1968), but a $15 \mathrm{~mm}$ flow cell is used in the colorimeter to enhance sensitivity.

As our interests are limited to the investigation of pure or almost pure anti-D sera, the choice of test cells is less critical and only requires the presence of a double dose of the $D$ antigen. $R_{2} R_{2}$ cells are unlikely to be available as fresh cells in sufficient quantity for routine work, so we recommend the use of group $O R_{1} R_{1}$ cells. Pooled cells are used to overcome the effect of individual variation in the strength of the $D$ antigen. Donations from three or four volunteers are taken into acid citrate dextrose and used within 48 hours of collection. The red cells are washed three times in isotonic saline and $20 \mathrm{ml}$ of the packed cells is suspended in a solution containing $30 \mathrm{ml}$ of $30 \%$ bovine albumin, $15 \mathrm{ml}$ of inert group $\mathrm{AB}$ serum, and $35 \mathrm{ml}$ of isotonic saline.

PREPARATION OF WORKING STANDARD Anti-D sera are collected from donors known to have albumin titres greater than 1:128 against group $O R_{1} R_{1}$ cells. The specificity of the antibody is checked against a comprehensive panel of fully genotyped red cells by saline, albumin, enzyme, and indirect antiglobulin techniques. Sera with albumin anti-C, or saline anti-D titres greater than 1:32 or with other irregular antibodies at a titre of $1: 4$ should not be included in the working standard.

Ten sera obeying these criteria are pooled, the 
specificity of the pool is confirmed, and the anti-C and anti-D titres are checked by saline and albumin techniques. The anti-C titre of the pooled serum should be less than $1: 8$ by albumin techniques, against group $O \mathrm{r}^{\prime} \mathrm{r}$ red cells. The saline anti-D content should be less than $1: 8$ against group $\mathrm{O} \quad \mathbf{R}_{2} \mathbf{R}_{2}$ red cells. No other irregular antibodies should be detectable.

The pooled serum is dispensed initially into $10 \mathrm{ml}$ volumes and stored at $-25^{\circ} \mathrm{C}$. For use the serum is dispensed into $0.2 \mathrm{ml}$ volumes and kept at $-25^{\circ} \mathrm{C}$. Every care is taken not to thaw and refreeze the serum more often than necessary.

A 1:10 dilution of the working standard in inert group $\mathrm{AB}$ serum dispensed and stored in the same manner serves as a control for the dilutions of the working standard used in the procedure.

CALIBRATION OF WORKING STANDARD Each ampoule of the International anti-D typing serum (Goldsmith et al, 1967) contains between 10 and $13 \mu \mathrm{g}$ of antibody protein (HughesJones and Stevenson, 1968). A mean value of 11.5 $\mu \mathrm{g}$ per ampoule has been assigned to this standard for the purpose of calibrating a working standard. Because the amount of freeze-dried serum per ampoule is $0.5 \mathrm{ml}$, each ampoule is reconstituted with $1 \mathrm{ml}$ of $0.45 \%$ sodium chloride to give an isotonic solution containing $11.5 \mu \mathrm{g}$ of antibody protein per $\mathrm{ml}$.

Ten dilutions of the International Standard are made in buffered saline $(p \mathrm{H} 7 \cdot 2)$ from $1: 100$ to $1: 1,000$. The serum to be calibrated is also diluted so that the results obtained on the colorimeter fall between the results of the highest and lowest dilutions of the International Standard. An estimate of suitable dilutions for the working standard is made from the results of manual titrations.

The sample tray of the AutoAnalyzer is loaded with each dilution of the International Standard in order of antibody concentration followed by each dilution of the prepared working standard. Alternate sample cups between each serum dilution contain $20 \%$ group $\mathrm{AB}$ inert serum in isotonic saline.

The optical density (O.D.) values given by each dilution of the International Standard are plotted on linear graph paper and the values of the dilutions of the working standard are related to the graph. The content of antibody protein in $\mu \mathrm{g} / \mathrm{ml}$ in the serum is calculated from the formula:

Concentration of unknown $=\frac{A \times C}{B}$

Where $A=$ the reciprocal of the dilutions of the working standard.

$B=$ the reciprocal of the equivalent dilution of the International Standard serum that gives the same O.D. reading as the diluted test serum. (This is obtained from the graph (Fig. 1) where

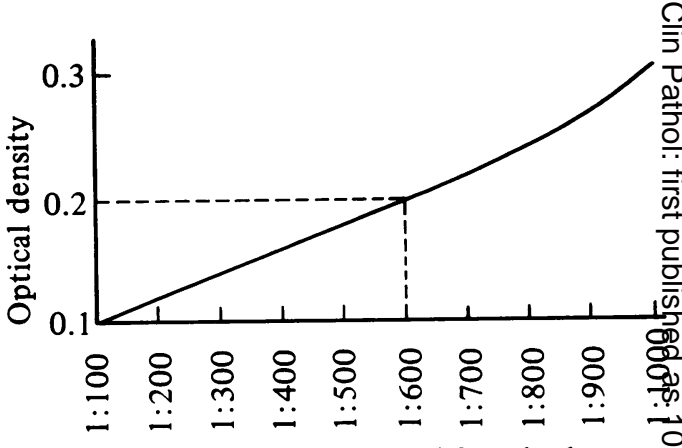

Dilutions of International Standard

Fig. 1 Graph of typical results of the International Standard anti-D serum where the O.D. value of 0.2 represents an International Standard dilution of 1: 600 (for further explanation see text).

the O.D. of the 1:500 dilution of the working standard is 0.2 and therefore equivalent to an International Standard dilution of $1: 600$.)

$\mathrm{C}=$ concentration of the International Stand dard serum in $\mu \mathrm{g} / \mathrm{ml}$.

For example:

Concentration of the working standard $=$ $\frac{500 \times 11.5}{600}=9.6 \mu \mathrm{g}$ of antibody protein per $\mathrm{m} \vec{\omega}$

This calculation is applied to each dilution of the working standard provided it falls within the limits of optical density. The average of the results from all the dilutions is then taken as the value of the working standard in $\mu \mathrm{g} / \mathrm{ml}$ of ant $\mathrm{P}$ body protein. The whole procedure is repeate $\vec{\theta}$ and the average of the two results obtained taken as the true value of the working standar This value is used in the quantitation of unknown sera against the working standard.

If it is required to translate the value in $\mu \mathrm{g} / \mathrm{mg}$ to a conventional albumin, antiglobulin, of. enzyme titre, it will be necessary to calibrate the appropriate technique against the AutoAnalyze results for the particular laboratory concerned For example, a number of test sera are carefull titrated by the usual manual albumin technique several experienced technicians doing the tests i parallel. The mean of all their results over a range of antibody strengths is taken as the equivalent albumin titre. In our laboratory an antibody concentration of $1.0 \mu \mathrm{g} / \mathrm{ml}$ has an equivalent albumin titre of $1: 33$.

QUANTITATION OF ANTI-D SERA

The specificity of the sera to be tested must be confirmed by saline, albumin, enzyme, and antiglobulin techniques against a panel of fulf genotyped red cells. Sera that contain only anti-B (or anti-C+D when the anti-C content is less than one fifth of the anti-D content) are suitable for quantitation using this technique.

An assessment of the probable anti-D titre 


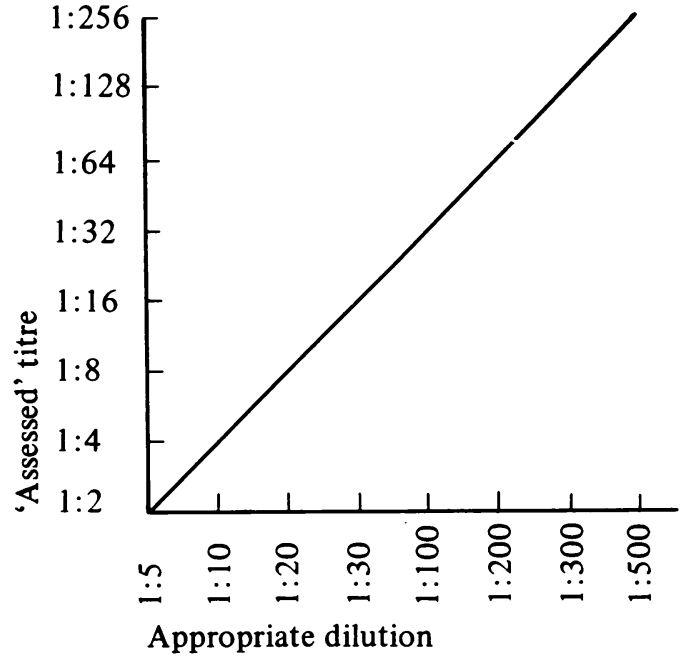

Fig. 2 Curve showing the appropriate dilution of a test serum to be made according to its 'assessed' titre.

made by an experienced technician at the time of checking the specificity of the antibody. A reliable assessment can be based on the strength and speed of reaction of the indirect antiglobulin test using group $O \mathbf{R}_{1} \mathbf{R}_{\mathbf{2}}$ red cells. The 'assessed' titre serves as a guide to the appropriate dilution of the test serum for the AutoAnalyzer. Suitable dilutions based on assessed titres are given in Figure 2.

At least six dilutions of the working standard are made in buffered saline, the range of dilutions depending on the concentration of the working standard and upon the sensitivity of the AutoAnalyzer in detecting rhesus antibodies. A standard containing $20 \mu \mathrm{g} / \mathrm{ml}$ is diluted between $1: 1,000$ and $1: 3,000$. The effect of a weak contaminating anti-C in the working standard is eliminated by this high dilution.

Test sera are diluted according to their 'assessed' titres. Only one dilution of each test serum need be made providing its OD value falls within the values of the standard dilution curve.

The OD values for the working standard are plotted on linear graph paper. The OD value for each diluted test serum is related to the graph and the $\mu \mathrm{g}$ per ml content is calculated from the formula:

Concentration of test $=\frac{\mathrm{A} \times \mathrm{C}}{\mathrm{B}}$

Where $A=$ reciprocal of the dilution of the test serum; $\mathbf{B}=$ reciprocal of the equivalent dilution of the working standard serum that gives the same OD reading as the diluted test serum; and $\mathrm{C}=$ the concentration of the standard serum in $\mu \mathrm{g} / \mathrm{ml}$ of antibody protein.

The equivalent albumin titre of the test serum may be calculated from the above formula by substituting $C$ for the equivalent albumin titre of the working standard serum.

\section{Reproducibility of the Method}

Parallel investigations of the same anti-D sera $\stackrel{\text { 赵 }}{5}$

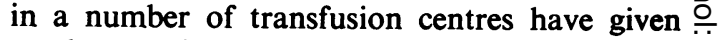
results agreeing to within $\pm 25 \%$ (Moore, 1969).

A single anti-D serum investigated on $20 \%$ separate occasions gave values between 1.2 and $1.7 \mu \mathrm{g} / \mathrm{ml}$, with a mean value of $1.45 \mu \mathrm{g} / \mathrm{ml}$ and a variation from the mean of $17 \%$.

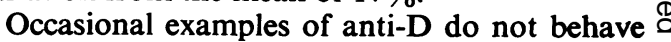
characteristically and are unsuitable for auto- के mated quantitation. If, for example, the manually $\vec{\circ}$ assessed titre is markedly different from that obtained on the AutoAnalyzer, the serum should $\vec{\omega}$ be fully titrated manually and reported as such. Further research may elicit reasons for the ? exceptional behaviour of certain antibodies.

\section{Discussion}

The routine titration of antibodies by manual techniques is liable to variation due to minor $\mathbb{Q}$ fluctuations in test conditions and the subjective $\frac{3}{0}$ reading of scores and end points. This is exem- $\stackrel{\mathbb{Q}}{-}$ plified by the diversity of results reported by $\vec{\theta}$ Goldsmith et al (1967) when they distributed their proposed International Standard to 29 . reputable serological laboratories. Different investigators reported albumin titres ranging from $1: 8$ to $1: 1024$, and antihuman-globulin titres from $1: 64$ to $1: 1024$. Under these conditions it $\frac{}{\Phi}$ is clear that a patient moving from one district $\varrho$ to another during pregnancy could be wrongly interpreted as producing a marked change in her serum antibody content.

Using a standard for comparative purposes during the investigation of unknowns allows adjustments to be made to compensate for daily:variation in manual techniques.

While the Technicon AutoAnalyzer is not of $\delta$ practical value for routine antibody screening due to the limitation of suitable fresh genotypedo red cells, it is extremely useful for accurate and reproducible antibody quantitation. The machine? can be set for maximum sensitivity for the antibody under investigation and the supply of \% appropriate fresh red cells is not difficult. The $N$ read-out is entirely objective, and with suitable $\mathcal{C U}^{N}$ calibration a result can be recorded in terms of 0 micrograms of anti-D protein per millilitre, together with its equivalent albumin titre.

Because the use of a standard at six dilutions is $\stackrel{\oplus}{\rightarrow}$ inherent in the method, workers using machines 0 in distant places will produce similar results on $\overline{0}$ the same test sera. Accuracy between laboratories $\stackrel{\square}{\circ}$ will be even greater if all workers use the same $\stackrel{\mathbb{Q}}{\mathscr{Q}}$ standard, and for this reason the present authors make a plea for the use of the International Standard anti-D typing serum for the preparation of a pooled domestic standard in each laboratory. 
It is important that agreement is reached on the assignment of a fixed value for the International Standard. For the present standard we propose a mean value of $11.5 \mu \mathrm{g} / \mathrm{ml}$ antibody protein.

The automated technique is not a substitute for any part of the full manual investigation of a serum. It is essential to continue with comprehensive manual screening techniques using a suitable panel of genotyped cells in order to determine the specificity of the antibody or mixture of antibodies.

Certain mixtures of antibodies will preclude the automated technique for anti-D quantitation. For example, if the red cells being used in the machine are $R_{1} R_{1}$, a strong anti-C in the presence of a moderately strong anti-D will give an accumulated titre. Similarly, other antibodies outside the rhesus system may influence the results.

The ultimate judgement of the value of the automated technique will be based on a comparison of antibody levels reported in relation to the outcome of pregnancy. In a preliminary communication, Tovey and Fraser (1969) ha $\overline{\overline{\overline{x e}}}$ indicated good correlation, and we may therefore anticipate the day when obstetricians and paedia ricians will prefer a gravimetric analysis of serum antibody content.

We wish to thank Dr K. L. G. Goldsmith, from the Blood Group Reference Laboratory, for supplies of the International Standard antityping serum.

\section{References}

Goldsmith, K. L G , Mourant, A. E and Bangham, D. R. The international standard for anti- $R h_{0}$ (anti-D) incorsplete blood-typing serum. Bull. Wld Hlth Org., 36, 435-445,

Hughes-Jones, N. C., and Stevenson, M. (1968). The antion content of IgG preparations for use in the prevention 6 f Rh haemolytic disease. Vox Sang. (Basel), 14, 401-408.0

Marsh, W. L., Nichols, M., and Jenkins, W. J. (1968). Automated detection of blood group antibodies. J. med. Lab. Tech., $\mathbf{2 5}$, 335-342.

Moore, B. P. L. (1969). Automation in the blood transfusion laboratory. Canad. med. Ass. J., 100, 381-387.

Tovey, G. H., and Fraser, I. D. (1969). Significance of antibofy nitrogen levels in $R h$ haemolytic disease, Technic Symposium, London.

\section{Reports and Bulletins prepared by the Association of Clinical Biochemists}

The following reports and bulletins are published by the Association of Clinical Biochemists. They may be obtained from TiR Administrative Office, Association of Clinical Biochemists, 7 Warwick Court, Holborn, London, WC1R 5DP. The prices include postage, but airmail will be charged extra. Overseas readers should remit by British Postal or Money Order. If this is not possib $\vec{E}$ the equivalent of 10 s. is the minimum amount that can be accepted.

\section{SCIENTIFIC REPORTS}

3 Automatic Dispensing Pipettes. An assessment of 35 commercial instruments 1967 P. M. G. BROUGHTON, A. H. GOWENLOCK, G. M. WIDDOWSON, and K. A. AHLQUIST 17 s (\$2)

\section{An Evaluation of 5 Commercial Flame Photometers suitable for the Simultaneous Determination of Sodium and Potassium March 1970 P. M. G. BROUGHTON and J. B. DAWSON $17 \mathrm{~s}(\$ 2)$}

TECHNICAL BULLETINS

9 Determination of Urea by AutoAnalyzer November 1966 RUTH M. HASLAM 8s $6 \mathrm{~d}(\$ 1)$

10 Filter Fluorimeters. A comparative list of 14 instruments March 1967 HANNELORE BRAUNSBERG (Re-issued in response to demand. Text still valuable. list now out of date) $8 \mathrm{~s} 6 \mathrm{~d}(\$ 1)$
11 Determination of Serum Albumin by AutoAnalyzer using Bromocresol Green October 1967 B. E. NORTHAM and G. M. WIDDOwson 8s 6d (\$1)

13 An Assessment of the Technicon Type II Sampler Unit March 1968 B. C. GRAY and G. K. McGoWAN 8s 6d (\$1)

14 Atomic Absorption Spectroscopy. An outline of its principles and a guide to the selection of instruments May 1968 J. B. DAWson and P. M. G. BROUGHTON 8s 6d (\$1)

15 A Guide to Automatic Pipettes (2nd edition) June 1968 P. M. G. BROUGHTON 8s 6d (\$1)

16 A Guide to Automation in Clinical Chemistry May 1969 P. M. G. BROUGHTON 12s 6d (\$1.50)
17 Flame Photometers (2nd edition) 1969 P. WILDING 12s 6d (\$1.50)

18 Control Solutions for Clinical Biochemistry (4th edition) March 1970 P. M. G. BROUGHTON $12 \mathrm{~s} 6 \mathrm{~d}(\$ 1.50)$

19 Spectrophotometers. A comparative 음 list of low-priced instruments readily available in Britain May 1970 C. E. WILDE and P. SEWELL 12s 6d (\$1.50)

20 Quantities and Units in Clinical Biochemistry June 1970 P.M.G. BROUGHTON $12 \mathrm{~s} 6 \mathrm{~d}(\$ 1.50)$ More than 30 copies in units of 10 at 48 